\title{
Review on the correlation of geological conditions and seismic damage of underground structures
}

\author{
Chen shijun ${ }^{1, a}$, Wang Zengliang ${ }^{1, b}$, He Chunfeng ${ }^{1, c}$ \\ ${ }^{1}$ East china university of technology,school of civil and architecture engineering, Nan Chang,China \\ ashijun_chen@ecit.cn, ${ }^{b} 1538419208 @ q q . c o m,{ }^{c}$ chunfeng_he@ecit.cn
}

Keywords:geological conditions, seismic damage, underground structures

Abstract:Many large underground structures have witnessed great damage in recent earthquakes. To study damage pattern of underground structures during seismic events, understanding different effects on underground tunnels induced by different factors during seismic shaking is also very important. This paper focuses on the construction conditions of structures such as the overburden depth, and fault displacement affecting the seismic damage of underground structures during earthquakes.

\section{Introduction}

Generally, it is assumed that underground structures are much safer to earthquake loading, compared to above surface structures. However, many large underground structures have witnessed great damage in recent earthquakes, such as the 1976 Tangshan, China earthquake, the 1995 Kobe, Japan earthquake, the 1999 Chi-Chi, Taiwan earthquake, and the 1999 Kocaeli, Turkey earthquake, and some more recent earthquakes such as the 2004 Niigata, Japan earthquake, and the 2008 Wenchuan, China earthquake. in this paper,

A detailed bibliographic study on the performance of large underground structures during past seismic events, in which the correlation of damage degree and construction conditions such as overburden depth, rock conditions, fault distance and construction methods has been examined.

\section{Overburden depth}

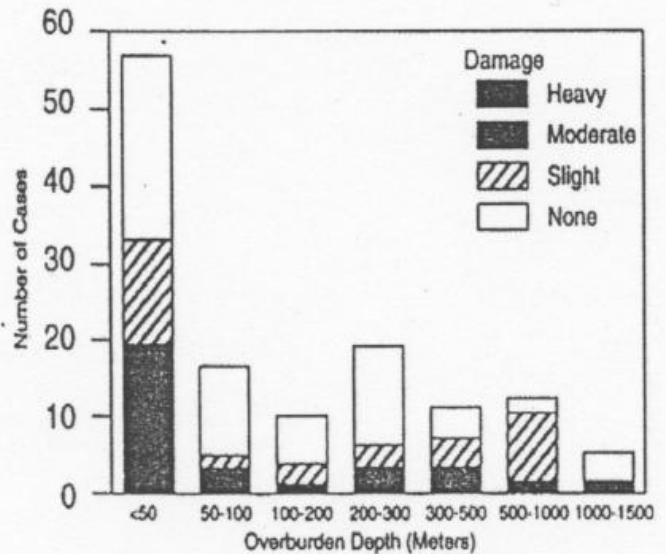

Figure 1 Influence of overburden depth on damage (Sharma\&Judd,1991)

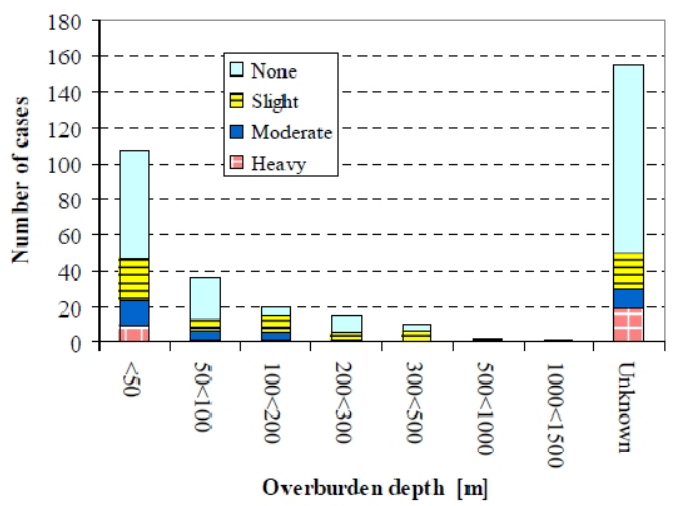

Figure 2 Effect of overburden depth on damage (Corigliano, 2007) 
Less damage would be expected with increasing depth, due to that usually the shear modulus of soil deposits increases with depth, and on the other hand, ground motion amplitude reduces with depth (Carpenter \& Chung, 1986). Wang(1985) also concluded that intensity underground decreases rapidly with depth to approach a constant value.

According to previous studies, deep tunnels are safer than shallow tunnels(Dowding \&Rozen, 1978; Owen \& Scholl, 1981; Röshoff, 1989). Pratt et, al (1980) analyzed the existing database for tunnels, shallow underground openings, mines and other deep structures, and found that more damage occur in shallow, near-surface tunnels than in deep mines, with data being particularly sparse data below 500m. It can be shown from the database collected by Sharma\&Judd(1991) thatthere is rather less damage at depths greater than $50 \mathrm{~m}$, and almost no damage for depths greater th00m, as shown in Figure1. According to the extended database by Corigliano(2007), the level of damage rapidly decreases as the depth increases, as clearly shown in Figure 2.

\section{Rock conditions}
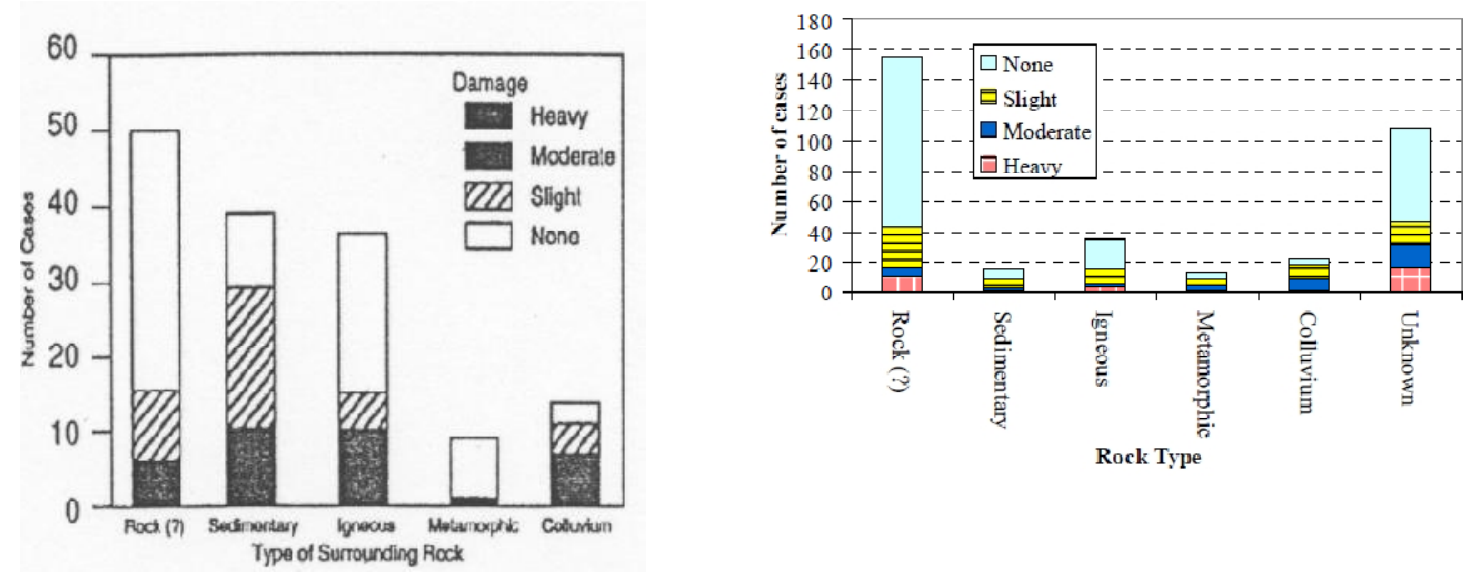

Figure 3 Influence of rock types on damage Figure 4 Effect of rock types on damage (Corigliano, 2007)

(Sharma\&Judd,1991)

Damage is closely related to the properties of the rock surrounding the underground structures, probably due to that the responses of underground facilities is affected by material properties of the rock that control the seismic wave and attenuation behavior(Sharma\& Judd, 1991).Seismic waves propagate faster in hard and dense materials, and thus less energy will be released at places where the tunnels lie in ground that is harder than the tunnel structure, meaning that such tunnels will tend to deform with the ground and suffer less damage. On the other hand, if the tunnels lie in relatively weaker ground they will absorb larger amounts of energy and thus suffer greater damage. Concrete linings can particularly be damaged easily by ground displacement or ground squeeze where soft and hard grounds meet, as soft and hard grounds behave differently during earthquakes (Hashash, et al, 2001).

Okamoto (1973) reviewed damages to railway tunnels in 1923 Kanto earthquake. The rock types were introduced by Sharma\&Judd(1991) to correlate the geology condition with damage levels, as shown in Figure3, and it could be clearly shown that underground openings constructed in colluvial materials are more vulnerable to earthquakes since such the damaged proportion of such openings is relatively larger than that of non-colluvial material. The collapse of Daikai station and serious damage of Kamisawastation, may due partly to their construction materials, which constitute of an alluvial clayey deposit together with relatively soft materials in upper layer, as shown in Figure4. Based on the extended database, Corigliano (2007) concluded that proportionally the level of high 
damage in soil tunnels is quite high compared with the recorded cases, as shown in Figure5. The higher vulnerability of cut-and-cover tunnels as compared to bored tunnels is also probably due in part to the softer geologic materials surrounding cut-and cover structures(Power,1998). Besides, underground structures suffered less effects in consolidated than unconsolidated rock(Pratt et, al 1980).

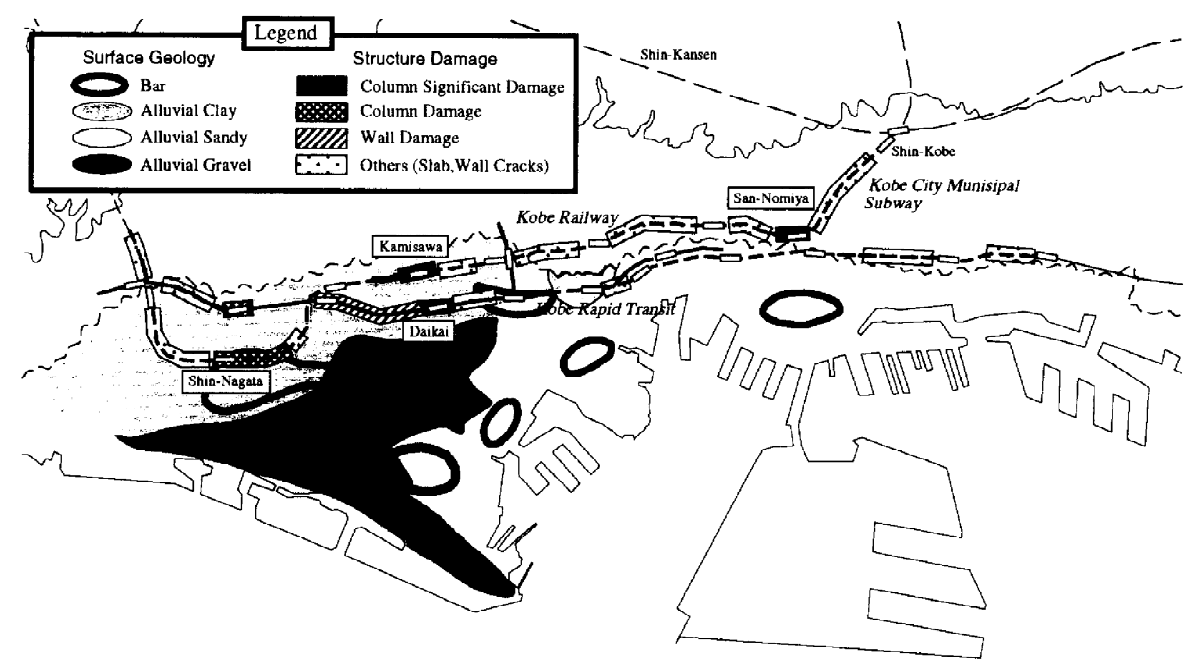

Figure5 Geological conditions and the distribution of damaged stations (Senzai, 1997)

Underground structures crossing geological weak zones such as weathered zones and fracture zones are more vulnerable to earthquakes, since earthquake motions are amplified(Murano Takewaki, 1984) or stress concentration occurred. Okamoto (1973) reviewed the effects of different weak conditions on the damage proportion, as shown in Table 1. The collapsed tunnel sections in Turkey was probably related to their locations in weak, highly fractured clay gouge, and the damage was found in the central section of the Bantaki Tunnel where it passes through an originally fractured zone during 1995 Kobe earthquake(Koji Uenishi, 2001), and other subsurface structures such as mountain tunnels in sound rock are less affected by an earthquake even if it is a very large tunnel.

Table 1 Correlation of soil types and damage rate (Okamoto, 1973)

\begin{tabular}{|c|c|c|c|c|}
\hline Type of soil & Hard rock & Soft rock & Rock with joints & $\begin{array}{c}\text { Soil or Soil \& } \\
\text { Gravel }\end{array}$ \\
\hline Damage Rate & $16 \%$ & $40 \%$ & $44 \%$ & $61 \%$ \\
\hline
\end{tabular}

\section{Fault displacement}

Several earlier case histories of tunnel damage due to fault displacement can be found in the literature, and the relatively well-documented cases are shown in Table 2, among which the collapse of Bolu tunnel was arguably affected by the fault fracture, and other three tunnels suffered substantial failures. According to Dowding\&Rozen (1978), compared with other damage cases, more severe but localized damage may be expected when tunnel is crossed by a fault that displaces during an earthquake, while damage level depends largely on the fault displacement, and total collapse of a tunnel is even found associated only with movement of an intersecting fault. Bäckblom \& Munier (2002) also concluded that damage in concrete linings was often within 5-10 
$\mathrm{m}$ from the fault that moved, evidencing that the effects of faulting would be extremely local in nature.

Table 2 Tunnel damage induced by fault displacement

\begin{tabular}{|c|c|c|c|c|c|c|}
\hline \multirow[b]{2}{*}{ Tunnel } & \multirow[b]{2}{*}{ Earthquake } & \multirow[b]{2}{*}{$\mathrm{Mw}$} & \multicolumn{4}{|c|}{ Offset } \\
\hline & & & Fault & type & $\begin{array}{l}\text { Amplitude } \\
\text { (m) }\end{array}$ & Reference \\
\hline Wrights tunnel & $\begin{array}{c}1906 \text { San Francisco } \\
\text { earthquake }\end{array}$ & 7.7 & $\begin{array}{c}\text { San } \\
\text { Andreas } \\
\text { Fault Zone }\end{array}$ & $\begin{array}{l}\text { strike } \\
\text { slip }\end{array}$ & 1.7 to 1.8 & $\begin{array}{l}\text { Prentice \& } \\
\text { Ponti } 1997\end{array}$ \\
\hline $\begin{array}{l}\text { Urban Kern Country } \\
\text { railway tunnel }\end{array}$ & $\begin{array}{c}1952 \text { Kern Country } \\
\text { earthquake }\end{array}$ & 7.5 & $\begin{array}{c}\text { White Wolf } \\
\text { Fault }\end{array}$ & $\begin{array}{c}\text { reverse }+ \\
\text { strike } \\
\text { slip }\end{array}$ & 1.3 & $\begin{array}{l}\text { SCECDC } \\
2002\end{array}$ \\
\hline Inatori tunnel & $\begin{array}{l}1978 \\
\text { Izu-Oshima-Kinkai } \\
\text { earthquake }\end{array}$ & 7.0 & Unknown & $\begin{array}{l}\text { strike } \\
\text { slip }\end{array}$ & 1 & $\begin{array}{c}\text { Kawakami } \\
1984\end{array}$ \\
\hline $\begin{array}{c}\text { Twin Bolu tunnels } \\
\text { (Üstanbul-Ankara } \\
\text { highway) }\end{array}$ & $\begin{array}{c}1999 \text { D.zce (Turkey) } \\
\text { earthquake }\end{array}$ & 7.2 & $\begin{array}{c}\text { North } \\
\text { Anatolian } \\
\text { Fault Zone }\end{array}$ & $\begin{array}{l}\text { strike } \\
\text { slip }\end{array}$ & collapse & GEES 2002 \\
\hline
\end{tabular}

\section{Conclusions}

from above investigation we can draw the conclusion that Fault displacement may account for some serious damage of structures crossing active fault. Underground structures crossing the geological weak zone are more susceptible to damage during earthquake. Especially, the aseismicity of a structure may not be improved by only placing stiffer support.

\section{Acknowledgements}

This work was financially supported by the National Natural Science Fund(51668002, 51568001), $\mathrm{t}$ he Jiangxi Provincial Natural Science Fund.(20161BAB216145, GJJ160562, GJJ150567) and the R esearch Start-up Fund of ECUT (DHBK2013203,DHBK2013202).

\section{References}

1. American Lifelines Alliance. (2001): Seismic fragility formulations for water systems. Part 1Guideline. ASCE-FEMA

2. Hashash, Y.M.A., Hook, J.J., Schmidt, B., Yao, J.I.C. (2001): Seismic design and analysis of underground structures. Tunnelling and Underground Space Technology,16, 247-293.

3. Power, M.S., Rosidi, D., Kaneshiro, J.Y. (1998): Seismic vulnerability of tunnels and underground structures revisited. Proc of North American Tunnelling'98. Newport Beach, CA: Balkema, Rotterdam, The Netherlands, p. 243-250.

4. Corigliano, M. (2007): Seismic response of rock tunnels in near-fault conditions. Doctoral thesis, Politecnico di Torino.

5. Okamoto, S. Tamura, C. (1973): Behavior of subaqueous tunnels during earthquakes. Earthquake engineering and structural dynamics, Vol. 1(3): p. 253-266.

6. Sharma, S., Judd. (1991): Underground opening damage from earthquakes. Engineering Geology, vol. 30, pp. 263.276. 
7. Genis, M., Gercek, H. (2003): A numerical study of seismic damage to deep underground openings. ISRM 2003-Technology roadmap for rock mechanics, South African Institute of Mining and Metallurgy.

8. Shirou, T., Akihiko, N. (1999): Seismic design of cut-and-cover tunnel based on damage analyses and experimental studies. QR of RTRI, Vol.40, No.3, Oct.

9. Senzai, S., Hajime, O., Takashi, M. (1997): A study of the damage of subway structures during the 1995 Hanshin Awaji Earthquake. Cement and Concrete Composites, 19 (3):232-239. 